\title{
THE CONSTRUCTION OF THE CONCEPT IN THE TECHNICAL-SCIENTIFIC, NO LITERARY AND IN THE SOCIAL NON LITERAY SPEACHES
}

\author{
A CONSTRUÇÃO DO CONCEITO NOS DISCURSOS \\ TÉCNICO-CIENTÍFICOS, NOS DISCURSOS LITERÁRIOS \\ E NOS DISCURSOS SOCIAIS NÃO LITERÁRIOS
}

\begin{abstract}
Versão para a língua inglesa do artigo "A construção do conceito nos discursos técnico-científicos, nos discursos literários e nos discursos sociais não literários" de autoria da Profa. Dra. Maria Aparecida Barbosa e publicado na Acta Semiotica et Lingvistica, Vol. 16 - Ano $35-\mathrm{N}^{\mathrm{o}} 1-2011$.
\end{abstract}

\section{Maria Aparecida Barbosa \\ (In memoriam) \\ University of São Paulo}

\begin{abstract}
This work tries to examine some important aspects of the concept, lexical and terminological levels of the gerative way of coding and decoding of the enunciation. The study of the structures and its functions of the pattern units in the cognitive and in the semiotic plans, are of great relevance, in the lexicological semantic and terminological area. We analyze here in one side the structural and functional complexity in the first level - archiconcept, metaconcept, metametaconcept, viewing the proposition of a typology in the concept field; on the other hand, some differences in concept and in method are examined between concept and definition, as basis to the methodology and configuration of semantic-conceptual traits of a concept.
\end{abstract}

Keywords: Archiconcept, Concept; Metaconcept; Cognitive Semantic; Lexical Semantic.

Resumé: Ce travail se propose d'examiner quelques aspects des niveaux conceptuel, lexematique et termitiologique du parcours génératif de l'énonciation de l'encodage et du decodage. L'étu<le «les stnictures et des fonctions des unités-standard du plan cognitif et du plan sémiotique est très important, dans le cadre des recherches lexico-logiques, sémantiques et terminologiques. On analyse ici, d'un côté, la complexité structurale et fonctionnelle des formations du premier niveau - archiconcept, méta-concept, méta-méta-concept, ayant en vue la proposition d'une typologie des champs conceptuels; d'un autre côté, on examine encore des différences conceptuelles et méthodo- logiques caractérisant le concept et la définition, de manière à obtenir des éléments pour la proposition d'une méthodologie permettant de formaliser les traits sémantico- conceptuels d'un concept donné.

Mots-clés: Archiconcept; Concept; Méta-concept; Sémantique Cognitive; Sémantique Lexicale. 
The articulation between cognitive and linguist semantic has become one of the paradigms of the language science, in its post-modern phase. We believe it is of great importance the development of models that can make possible to analyze and describe the status of cognition and its relations and the status of linguistic semiotization, specifically in this article as of the terminolization (Barbosa, 1998a: 25-44).

Therefore, we propose, in this work, to examine important aspects of the conceptual, lexemical, and terminological levels of the enunciation of coding and decoding. We analyze here, in one side, the structural and functional complexities of the first level - archiconcept, metaconcept, metametaconcept - , and on the other side we examine the conceptual and methodological differences between the process of conception and of defining, in order to obtain subsidies for a configuration methodology of semantic-conceptual traits of a concept. This makes possible, the characterization of different types of contexts, manifestation of speeches in which the concepts are made, by distinct processes. These contexts constitute the major sources from where are extracted the correspondent semantic-conceptual traits. Therefore, it is in the discursive instance that the cognition and semiosis are produced and the conceptualization of the fact is produced, it is built a concept and its linguistic manifestation. It is in the speech that is made that the conception traits are presented, in a codification procedure, and from this procedure that these traits are extracted.

\section{Conceptualization and gerative path of the enunciation}

The terms conceptualization and defining, concept and definition, not rarely, are used improperly, one by the other, or even, are considered equivalent. This relation of equivalence, however, is not justified, because they have different status and have specific conceptual qualities and constitute pattern units and process of distinct levels in the gerative path of the of coding and decoding the enunciation (PAIS, 1993: 562-578).

In fact, this path begins with the perception of "natural facts", that are structural substances, while potential information, for men, but that convert in structured substances, when caught by linguistic and sociolinguistic groups, of different ways, even if they maintain a core of biologic universal perception. In this first moment, of the perception, brings us to a second moment, the one that begins the process of conceptualization or the passage from the perception to the conceptualization. This comprehends in this stage, three types of semantic attributions: the latencies, in which the facts that are seen have their own identifying traits in a potential level, while structural substances of concept (HJELMSLEV, 1975: 53-64), apprehensible; the one of saliences in which some characteristics of the facts are highlighted by themselves, in the natural semiotics; and the one of the pregnancies, in which the subject enunciated individually and/or in group selects and chooses the traits that 
will configure the concept that have the fact in question (POTTIER, 1991: 61-69). In a third moment, the one that concludes the process of conceptualization (PAIS, 1993: 569-578), is the one that produces the mental models, of the conceptus (RASTIER, 1991: 73-114), notions or noemic groups - semantic conceptual traits - that correspond, in its turn, the cultural highlights, the constructed highlights, and in a ultimate analysis the designata.

These three moments - the perception, the beginning and the end of the conceptualization - constitute, the cognition path, understood as the apprehension and construction of a world vision.

For Cabré:

[...] la relación referente-concepto - uno de los ejes cuyo estudio presenta mayor dificultad científica, ya que solo es abordable a partir de hipótesis y comprobaciones empíricas indirectas: supone describir de qué modo los individuos conocen la realidad, cómo la perciben y cómo la conceptualizan. Esta relación es todavía hoy un tema muy controvertido. La polémica sobre si la realidad existe por si misma de forma objetiva, o si por el contrario existe solo a través de la percepción, no está todavía lo suficiente resuelta. Lo cierto es que los individuos aprehender la realidad mediante los distintos subsistemas de cognición, y en consecuencia se comportan de acuerdo con esta aprehensión (por ejemplo, evitan lo que consideran peligro, eligen los alimentos que les gustan, se orientan en un determinado espacio, etc.). Paralelamente, utilizar los sistemas expresivos, entre los que el lenguaje ocupa el lugar más importante, para aludir a esa realidad (...). La cognición es el resultado de un proceso psíquico que conduce al conocimiento. El problema de cómo el pensamiento humano comprende los objetos, y por abstracción, construye los conceptos, se encuentra en la misma base de la teoría terminológica. La cognición es un proceso mental que consiste en aprehender la realidad. Una teoría cognitiva ele la terminología debería ser capaz de explicar tres cuestiones básicas sobre el conocimiento relacionadas entre sí; a) cómo los individuos conceptualizan la realidad y estructuran el conocimiento; b) qué son los conceptos, cómo se establecen, cómo se interrelacionan y cómo se ordenan en la estructura del conocimiento; c) cómo se relacionar los conceptos y los términos".

\section{Leximization, actualization, semiosis}

The fourth moment of the gerative path of coding the enunciation is leximization and terminolization, that is, it corresponds to the conversion of concept in size-sign, that leaves the cognitive level to go to the semiotic level. The leximization here is understood as "la mise en lexeme" and terminolization as "la mise en terme", that is, the configuration of the concept in size-sign, in the same act of beginning the signification. In this way, the conceptual metasystem, the same one for all semiotics-objects of a culture, produce a range of conceptual semas that have the whole of sign matrix, for the different semiotic systems of a same culture, one of macrosemiotics, by means of the process of semiolization, lexemization, terminolization and semiotization. In these conditions, according to PAIS 
(1993: 188), the conceptus or lexes should be considered as lexias in potential, configurating as a starting point in the process of lexemization and terminolization. In this perspective, the lexemic or terminological meta-system, set of group of lexias with its expressions and contents (oversemema or polissemic sememas), in its network of relations, that constitute, by one hand, an instance of competence that preceeds and authorizes the lexia actualization in a concrete realized speech.

In this fifth moment, the contextualization, that is an epissemema (simultaneously, with the reduction of the semas of the sobressema, that is, the selection, determined by a situation of speech and of enunciation and the adding of context semas, in sintagmatical combination), that results the semiosis.

As we can see, the concept is situated in a pre-linguistic level, or, more exactly, pre-semiotic of designation, that can exist without the respective denomination, and that could have the perception and the knowledge of a fact, without possessing its denomination. In fact, he concepts maintain different types of relations with the denominations: there is, as we already said, concepts without denominations, there are concepts with only one denomination, there are concepts with two or more denominations, and it is also possible that one same denomination have two or more concepts. We should observe, with Cabré (1993: 172), that the formal vertent of the terminological unit receives in its terminology the name denomination (and also the term) and that, even that the use of term is used to designate the complete terminological unit (formed by denomination and concept), that also is used as a synonym of denomination.

This cycle proceeds with the interpretative way of the enunciatary subject, with the recuperation and the storage of the information, that lead, on the other hand, the subsequent process of conceptualization.

\section{Concept and Definition}

Considering this path Pottier shows the need of at least four levels of analysis.

a) Referential level, of the real or imaginary world (objects, dreams, memory pf speech, pictures....);

b) Conceptual level, of mental apprehension of the representation constituted from the referential level, at the same time coming from the social habits and of the needs of individual creatures;

c) Level of natural language, of the linguistic competence of the group; 
d) Level of produced text, resulting of many different components (linguistic, cognitive, contextual, situational, intentional), related to other semiotic systems (gestures, proxemic, illustrations...).

In this perspective, the ontology is the subject that deals with the first level, there is, the objects and its characteristics, organization and network of the natural universe; the conceptology, within the logic, deals with the nature of the concepts, its representation and of the relations that are established between them: the noemic is defined, therefore, as the study of the conceptual elements and of its relations, considered as necessary instruments, to describe the way the semantic as base of the natural languages work. It is of our interest here, from this point of view the conceptology and the noemic.

Once these levels are defined, levels of codification and analysis, it seems possible establishing with a great accuracy concept/definition, and the processes of conception/defining.

If the concept, as we have seen, is established in a pre-linguistic level, the definition results of an analysis and description of signical status, situating therefore, in the semiotic level, or at least concerning its starting point. The concept is the result of the interpretation of the natural and/or the cultural facts, while the definition is the result of an interpretation of lexical units. Concepting is the process of construction of a mental modeling that corresponds to a cultural aspect, and following that the choice/engendration of the lexic structure that can be seen in a more efficient way. This process is a starting point of the natural universe. Defining is the process of analyzing and describing the linguistic semema, to rebuilt the mental model: its starting point is the manifested linguistic structure.

It is interesting to highlight that the gerative path is done not only by the enunciating subject, that creates a new vocabulary or new term, but also through this subject, reusing vocabulary or pre-existing terms, in any situation of linguistic activity. Every time someone speaks, there is a reorganization of the linguistic system and of the conceptual metasystem. According to Cabré, the great majority of the concepts do not have rigid established frontiers, but limits that are proximal and diffuse. With the normatization, the concepts from then on artificially define its limits. Therefore, the instable and dynamic character of the cognitive level, the way the knowledge structure can fundamentally change by two causes: because there is a new axle, taking all the previous concepts to redefine in the light of this new dimension: or because there is a new way of seeing things, and the pre-existing concepts do not change axles, but change the position in its own axle.

We can see the acts of concepting or start any manifested speech are onomasiology processes that take as starting point the continuum amorf data of the experience, they go through the noemic level and arrive at the lexemic level, that in fact goes directly to the name, and whose product is the denomination. It is the path of the persuasive doing of the subject 
of the enunciation of codification, brought by who speaks and who writes. This subject of enunciation and codification, having the intention of a determined logical-conceptual pattern, can select different linguistic forms, that are susceptible of representing them, to start at least its manifested speech. From this path some concepts result: its semiotized representatives sign-size - and in later opportunities that are presented in manifested speeches.

\section{The organization of conceptual and lexical levels}

It is important to highlight that there are different types of conceptual and lexical fields as well as different types of relation that are established between the elements of a group of the first and of the last group, and there notion and structural differences between the concept field, lexical field, semantic field and its respective pattern units: concept, lexemas/vocabules/terms, sememas.

These questions arise, as we have seen in previous items, the model of the gerative path of the enunciation of codification and decodification, because each one of those fields is situated in different levels in this path: the conceptual field, the group of concepts is the result of the conceptualization process of "the knowledge of the world"- pre-linguistic, pre-semiotic, trans-semiotic: the lexical field, the group of lexemas, lexias, vocabules/ terms that have a common semic core and results of the lexemization process - converting the conceptualized information in linguistic significance; the semantic level, in one of its aceptions, constitute a group of sememas and result from the intersection of the significance of the lexical units in a lexical field. The relations that exist between the three fields are no simetric, because a lexical field contains and presumes its components in the conceptual and semantic fields; therefore, a conceptual field can not have, yet, the lexical fields and the semantic field that correspond to them. They constitute, however, non-mixable constructos, in a way that they belong to different levels of articulation and of analysis. From these three types of fields, we will present here, only the organization of the conceptual level.

\section{Structure of the Conceptual Level}

A concept, in a wide sense, constitutes, as we have explained above, a "mental model", conceptus, dialectically articulated to a cultural highlight or designatum. It is a group of conceptual semantic traits that, from our point of view, presents a great structural complexity, a sub-group of noemas, biophysical or universal,strictu senso concept; a subgroup of conceptual ideological semantic traits, intentional, modeling, metameta concept. In this last one, the noema is the most important, by opposition to the ideological of the previous sub-group, not so much highlighted as the intentional. These three sub-groups form the latu senso concept. 
Conceptual field as a unitary set

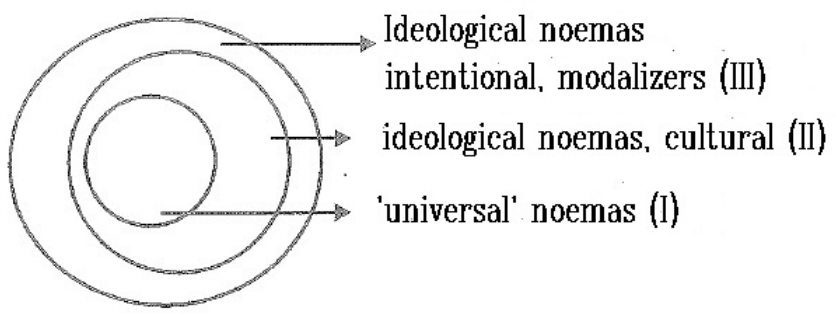

FIGURA 1

We think that is of great importance to say that, when you form a concept, it is generated simultaneously and necessarily three other concepts: its contrary and the following contradictory, because the men's thought works by positions, and between them, the relations of contrary and contradictory.

Therefore, when you create the concept, for example, at the same time is created its contrary $<<$ bad $>>$, and its respective contradictories $<<\sim \operatorname{good}>>$ and $<<\sim \operatorname{bad}>>$.

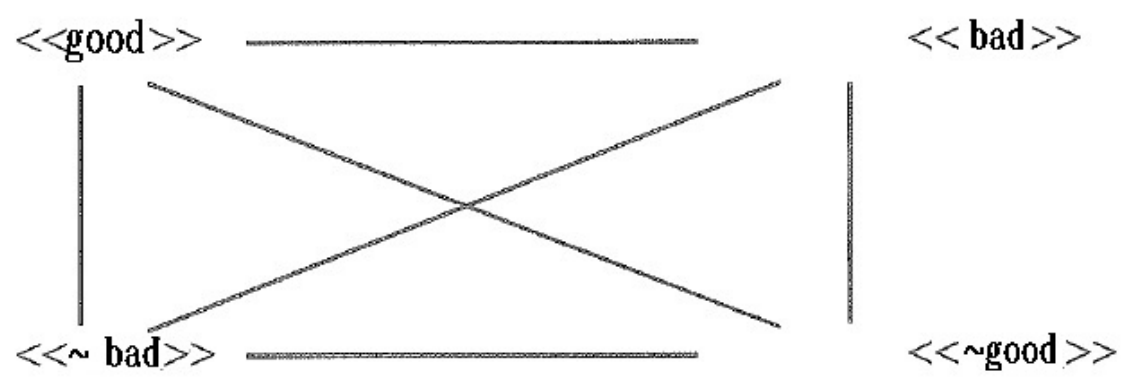

FIGURA 2

These relations "necessaries" and "non-eventual" authorize us to conceive the process of latu sensu intertextuality as initiated in the conceptual level of the gerative path of the enunciation, because a concept is necessarily related to another concept, constituting a conceptual microsystem.

Therefore, a latu sensu concept is a conceptual field, that already implicitly contains there three other concepts. We will call this case of full unitary conceptual, and by opposition to the empty unitary conceptual, which contains virtual concepts not yet engineered.

Different is the organization of the multiple conceptual group field, that contains various explicit latu sensu concepts, with a common semic core, presenting, each one of them, implicitly, its contrary and contradictory concepts.

Taking the sub-group of universal noems, that we here denominate as a stricto senso concept, in another perspective - the one of the contractive analysis, between 
different sociocultural groups, and of the comparative analysis of subgroups of the same culture - we come to the notion of archiconcept, resulting from the neutralization of the opposition that exists between different conceptions of a same fact.

The group of conceptual semantic traits of universal nature corresponds to an archiconcept (Béjoint e Thoiron, 19916: 512-526), since it neutralizes the conceptual differences between different languages. The archiconcept could be related to the prototype (Dubois, 1991) and to the intersection of the highlighted sense culturally obtained or formed (Hjelmslev, 1975: 53-64). Sustains and make possible interlinguistic and intersemiotic translatability processes.

If we compare the conceptual cutout of a natural 'fact', of an A Language to a B Language, we can say that the common traits constitute its archiconcept, that we can call archiconcept $_{1}$. Therefore:

archiconcept $_{1} \subset$ concept $_{1}$ of language $\mathbf{A} ;$
archiconcept $_{1} \subset$ concept $_{1}$ of language $\mathbf{B}$.

According to Béjoint and Thoiron:

L'archi-concept est vu ici comme une entité abstraite dont le statut, au plan philosophique, ne nous concerne pas. On r'e-connaitra seulement que 1 'archiconcept est en correspondance dans les diverses cultures, avec divers concepts. Le degré de similitude entre concepts, dits ici homologues, n'est pas préjugé (i. e. ni sour-estimé ni décrété a priori); il peut être grand on faible (...) ceci permet de reconstruire, pour chacune de ces langues, un embrion de concept. La réunion de ces ensembles embrionnaires de traits conceptuels constituerait l'embrîon d'un archi-concept...(1996: 516- 617).

The last part of the citation take us to the passage process in the amorf sense, structurable, in the formed sense, structured (Hjelmslev, 1975: 53-64), but common, mutatis mutandis.

We would say, therefore, that the conceptualization process, as a route, is much more complex than the transition from the amorphous sense to the 'formed sense' as explained by Hjelmslev. There are theoretical stages that constitute the conceptualization process, between one and the other. Indeed, in the transition from perception to conceptualization, there are, as we have seen, three stages of semantic attributes: the possible semantic attributes latencies of the 'objects' and 'processes' of natural semiotics; the protrusions, or attributes that stand out, in the structure, functioning and hierarchy of natural facts' ("to perceive"), pregnancies, ("to conceive"), in turn, constitute the result of man's activity, of the choices it does in the apprehension of those facts' (Pais, 1999: 13-50). 


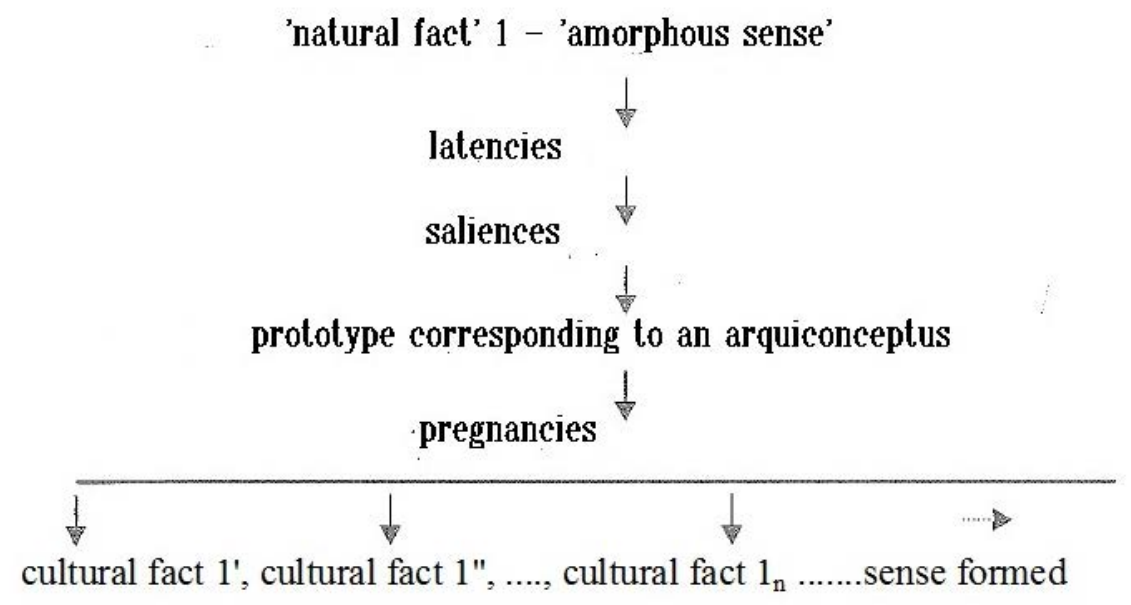

FIGURA 3

Thus, between the structured sense and the structured sense, there is the formation of a biophysical conceptual prototype, a noemic nucleus common to all cultures, which would correspond to the arch concept, or stricto sensu concept, first level of "formation", resulting from latencies and saliences. However, in the process of pregnancies, cultural noemas, specific to each culture, corresponding to the meta-concept, second level of "formation" and, within the same culture, euphoric or dysphoric "political discourses about it, begin to become visible. In fact, they generate metametaconcept, a subset of the semantic-conceptual features that shape it.

It seems to us that the notion of arch concept is fundamental, when the contrasting analysis of languages and cultures and, also, within the scope of the same language and culture, in the examination of the conceptual variation of the same 'fact': ensures the rigor of the study of variability and conceptual identities of the same 'fact', intercultures and intergroups. We believe that this notion of arch-concept completes the existing formalizations, which describe the structures of the cognitive level. It is also noteworthy, isomorphism, or formal identity between the processes of phonological, morphological, lexical, semantic, conceptual, even textual and their respective products: archiphoneme, archimorphism, archilexema, archisemema, archiconcept, architext, the latter ( Rastier, 2000: 445-470), as a result of the neutralization of differences between texts involved in a process of intertextuality.

The reflections above, authorize us to propose a typology of conceptual fields (Barbosa, 2000: 95-120). according to the number of elements criteria, the quality and quantity of elements that contain: conceptual field as a unitary group, conceptual field as an empty group, conceptual field as a multiple group, this last one, by its hand, constitutive of four types: the co-hyponyms one of natural semiotics, the one of the cultural co-hyponyms, the one of the modeling co-hyponyms and the parasynonyms. 


\section{A model for engendering and structuring a lato sensu concept}

Trying to illustrate, we present the formation of the concept of transgenic, in the Brazilian culture. Transgenic is a technical term that is very used these days and, as an adjective, is used to qualify biological beings, modified, in its genetical structure, through the development of technologies by genetic engineering. In its conceptual semantic core, we have the conceptual semas [+ living thing], [+ biology], (+ genetics], [+ structure], [+ engineering], [+ technology], [+ mutation]. We apply, preferentially, in food production. The sememical attributes and semantical-conceptual, in this level, could configure the intersection of all living beings and transgenic products, in the biological and technical level, that is, its archiconcept.

However, this innovation in production techniques and, consequently, in consumption habits, triggered a wide discussion, worldwide and, particularly, in our country. On the one hand, we have the 'modernity' speakers who defend the production and consumption of transgenic food, emphasizing the conceptual semas [+ modernity], [+ productivity], [+ abundance], [-price]. On the other hand, we have biologists, doctors and ecologists, among others, who point out possible dangers of innovation and who, for their part, highlight the semas [+ being alive], [+ biologia\}, [+ alimento], [+ natura1], [+ healthy1]. [+ insurance], [+ preservation], [+ environment], [+ tradition] of natural food products, corresponding, on the cognitive level, to metaconcept.

The question involves relevant political, economic and social problems. Successive or contrary speeches follow, in a serene or vehement tone, which include intentional, modalizers, manipulators conceptual semas, such as, for example, the opposition [+ modernity] / [+ preservation], [+ profit] / [+ public health ], among others, corresponding, in turn, at the cognitive or hyper-deep level, to the semantic-conceptual sets of metametaconceptions.

In the analysis of the speeches on this theme, it is possible to detect, at the level of deep semantics - the generative path of the enunciation of encoding and decoding (Pais, 1998: 271-311) - the tensions and conflicts at stake, in order to formalize the microsystems values underlying these speeches. In a dialectic semiotic model, we have, in deep semantics: 


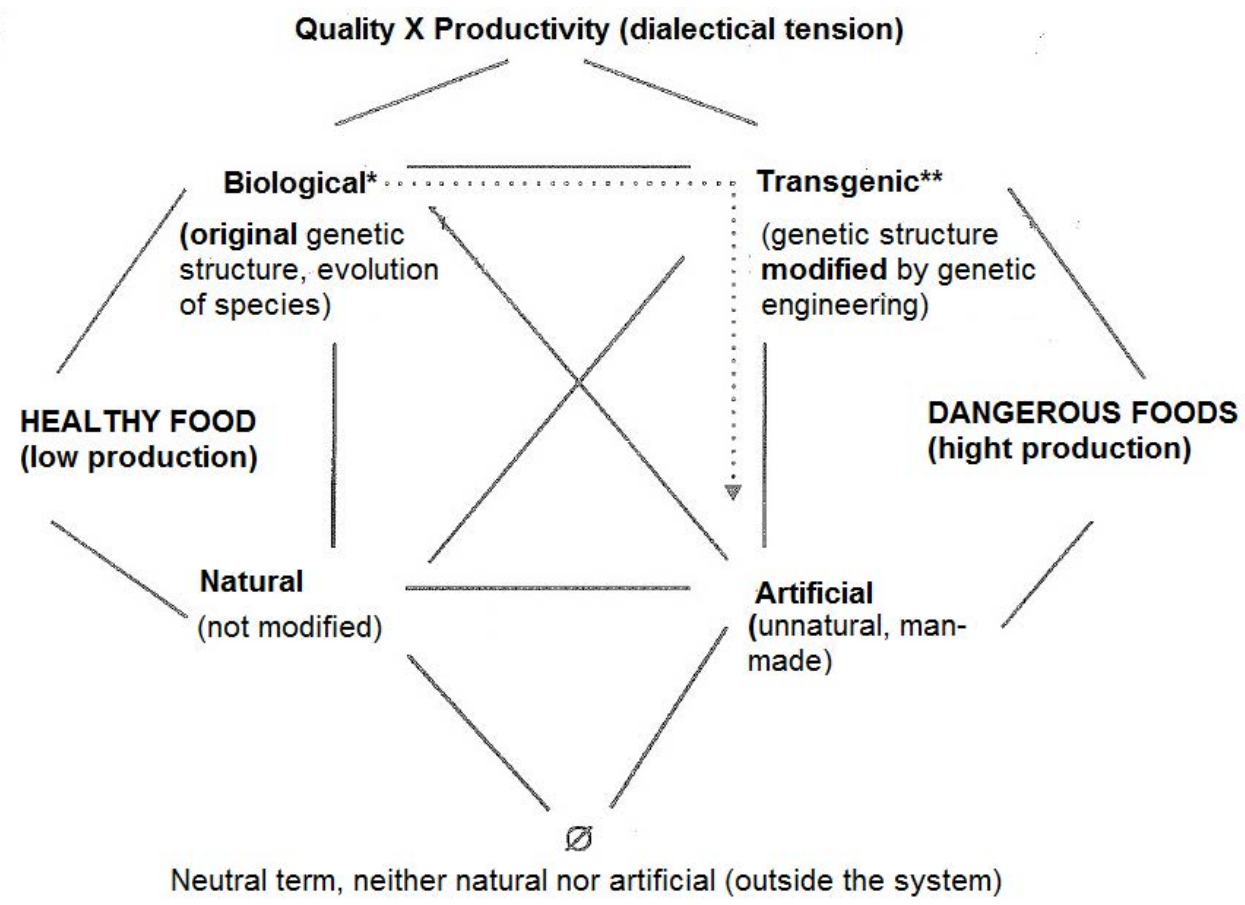

*BIOPHATE

**BIOMANUPHATE

Biological implies natural; transgenic implies artificial. Biological x transgenic coexist and are sustained in a dialectical tension, at the present time. A possible dialectical path of this semiotic model would be: from the biological, genetic engineering creates a transgenic, which implies an artificial, unnatural one. The biological $x$ natural combination constitutes the positive deixes healthy food; a transgenic vs. artificial combination constitutes a negative deixes for dangerous foods. The dialectical paths through the axes of opposites, contradictions and subcontractors, as well as their starting point, vary according to the political and / or ideological positions assumed by the enunciating subjects in their speeches

Thus, based on the lexical units, designationes, which are manifested in their speeches, the semas that integrate their linguistic sememas, it becomes possible to reconstruct the path from the cognitive level to the semiotic level, or, in other words, the transition from conceptualization to lexemization, from concept to denomination. We have, then, a reconstruction of the $<<$ transgenic $>>$ concept and its corresponding metaconcept and metametaconcept.

Preliminarily, we return to the initial scheme of the lato sensu concept, applying it to the $<<$ transgenic $>>$ concept. 


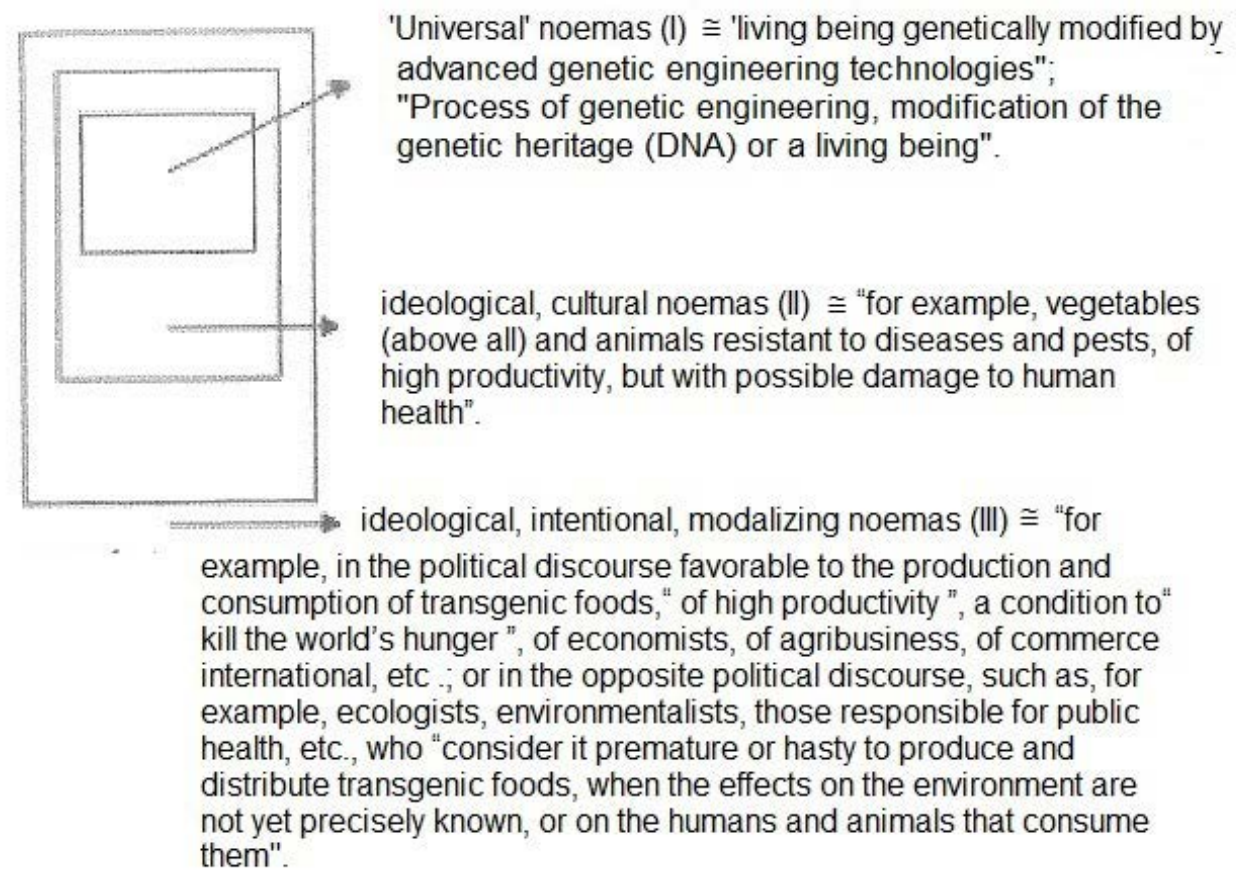

FIG. 5

It is possible to apply the general model presented above to the lato sense $<<$ transgenic $>>$ concept, in order to build a more rigorous formalization of the conceptual field as a unitary set: $<<$ transgenic $>>$, presenting its structure and the relationships that are established inside the lato sensu $<<$ transgenic $>>$ concept and the subsets of semantic-conceptual traits, that is, the misconceptions and the metametaconceptions that compose it. We have thus: 


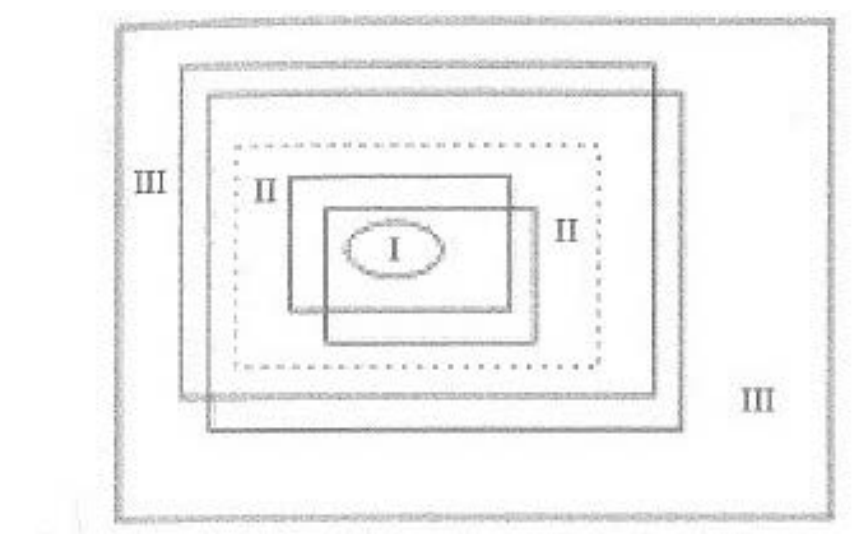

Where:
Consensus zones $\left[\begin{array}{l}\mathrm{I}=\{[+ \text { biological], [+ genetic structure], [+ } \\ \text { technology, [+mutation] } \\ \text { transgenic } \gg \cong \text { set of 'vniversal traits } \gg\end{array}\right.$
$I I=\{[+$ technology $],[+$ advancement], [+ productivity], [+ innovation],
$[+$ artificial] $] \cong$ netaconcept $\cong$ of cultural ideological traits

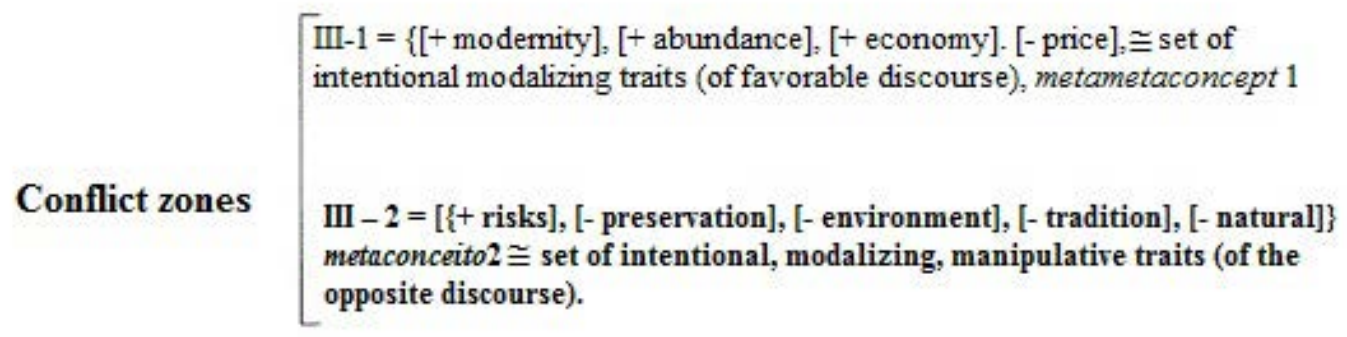

and where: $\langle<\ldots\rangle>=$ concept and $[\ldots]=$ conceptual semantic trait

\section{FIG 6}

We can observe that the subgroup of semantic-conceptual traits in Zone I, "universal", define archiconcept as a consensus, regarding the aspects of natural semiotics and of changing by men, of natural semiotics, a "world knowledge" shared by the community.

In the same way, the subgroups of semantic conceptual traits, ideological, cultural, in Zone II, that constitute the metaconcept, define some cultural consensus, another facet about the "world knowledge" shared by the same community, but different from community to community.

At last, the Zone III, is divided into two subgroups of semantic-conceptual traits, that constitute, respectively, the metametaconcept $t_{1}$ and the metametaconcept ${ }_{2}$ while the group of intentional traits, modelizers, manipulative (of favorable and contrary speeches).

So, we have, Zone III, as the zone of confrontation, the dispute, especially in the political speech, but also in the scientific, technological, economic discourses, etc. 
On the other hand, returning the semiotic model and the conceptual model built above, we can oppose $<<+$ biollogical $>>(\cong$ "genetic structure. Original, result of the evolution of species") and $<<$ transgenic $>>(\cong$ "modified genetic structure, by genetic engineering technologies"), which correspond, respectively, as we have seen, the concepts $<<$ artificial $>>$ and $<<$ natural $>>$, as well as the terms that express them.

The article published In Gazeta Mercantil (Pereira e Aliski, 4/09/2000: A-12) illustrates the zone of confrontation:

\begin{abstract}
"The Government is in a hurry to clarify doubts surrounding genetically modified organisms. For this, organizes meetings with the media and specialized lectures on biosafety. The initiative coordinated by the Ministry of Science and Technology seeks two objectives: to show that the country has advanced legislation on the subject and that Brazilian technicians are able to distinguish what is good for consumer health (...).
\end{abstract}

The Brazilian Government is convinced that it needs to urgently pass a steamroller in doubts about genetically modified organisms (GMOs) in the country. It started its part last week. The Ministry of Science and Technology arranged a meeting between the command of the National Technical Commission on Biosafety (CTNBio) and media professionals interested in spreading the transgenic theme to teach the relevance of scientific journalism in the modern world. Renowned technicians gathered, all members of CTNBio, for a lecture on biosafety. "We are fully aware of the need to incorporate scientific information into the daily lives of our population, using the mass media, whether printed or electronic", said Esper Cavalheiro, secretary of Science and Technology Policies and Programs, representative of Minister Romualdo Sardenberg, at the opening of the meeting. The discussion on biosafety has involved three corporations for almost a decade: scientists, investors and consumers. They appear in the composition of CTNBio, created by the government in 1995. Most are scientists - in principle, advocates of research. They are linked to the government by the umbilical cord of state and federal research institutes and universities. The representatives of the giants Novartis and Monsanto, present at CTNBiO, carry obvious positions. The team's greatest effort in this offensive to publicize transgenics is to film two things; that the country has advanced legislation in this matter and that Brazilian technicians have the professional capacity to discern what they do and what do not harm the health of the consumer. Consumers, the party that remains to be convinced, have two representatives, a public official from the government of Pará and a lawyer from Mato Grosso do Sul. Next week, the Strategic Studies Center of the Ministry of Science and Technology returns to the topic, in partnership with the Konrad Adenauer Foundation of São Paulo. There will be two days, 14 and 15, of debates on development and ethics in biotechnology. Meanwhile, the disclosure of the regulation regulating the labeling of products with GMOs has been postponed.

As to the kind of relation that is stablished between natural and transgenic food, we can say that they are co-hyponyms of natural and cultural semiotics.

Natural and Transgenic Food as co-hyponyms of natural and cultural semiotics:

Vol. 25 - Ano $44-n^{\circ} 2-2020$ 


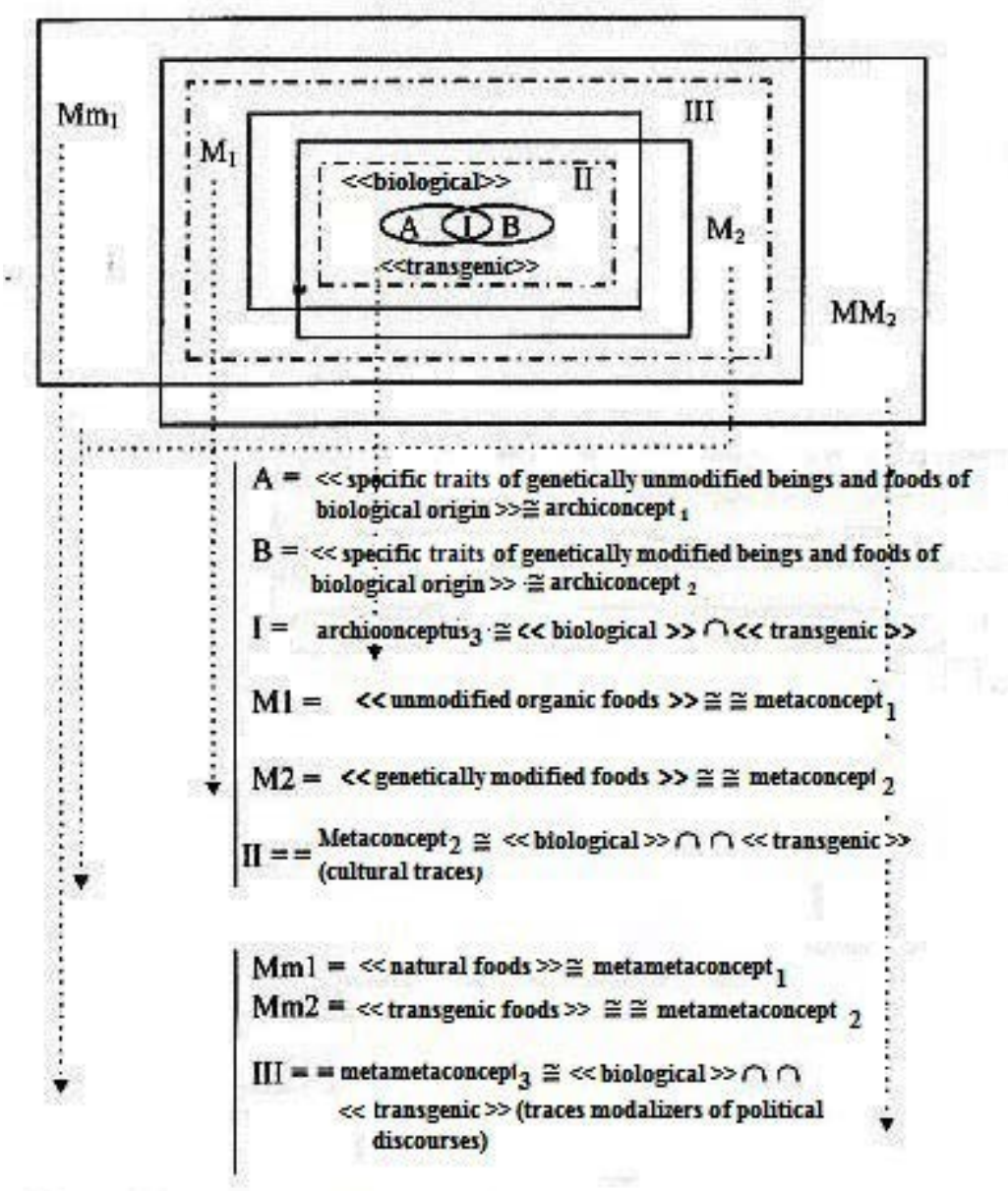

Fig. 7

Or if we prefer, in a more specific way, the formalization below, that presents a non-exhaustive sample, but, only illustrative of the semantic-conceptual traits extracted from favorable or contrary speeches regarding transgenic food.

Conceptus lato senso

Conceptus, natural organic food

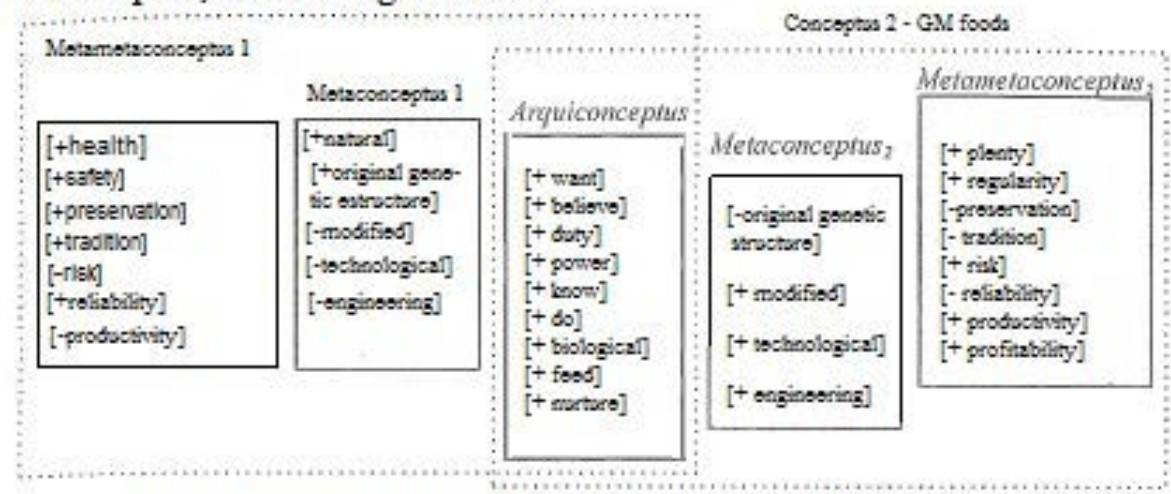

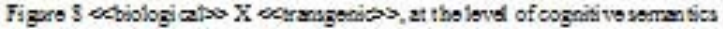




\subsection{The text in statu nascendi.}

It is time to highlight that not only we have a conceptual configuration more clear and precise of transgenic, corresponding to the term transgenic, but it also starts constituting a lexical/terminological field, much more richer in lexical units. At the moment, we can say transgenic genders, organisms that are genetically modified, among other, that appears as parasynonyms in this language of specialty.

\subsection{The transposition of concepts/terms to another area of specialty}

The signification verbal and non-verbal systems are panchronics by nature, once they follow the dynamics of social and cultural processes, from which they are generators and reflex. The diachronic, synchronic and panchronic approaches when of their analysis and description vary according to the various point of views and conceptions of the language that succeeds in the historical process of language sciences.

In post-modern linguistics, in which predominates the conception of language as a social, cultural, historical institution and as cognitive activity (PAIS, 1999), the predominating approach is of ample panchrony.

Applying this principle to language specialties and to terminology, the science that has an object of study, we can justify the analysis and description of the intense and interesting dynamics of concept transposition and its respective terms, from one area of specialty to another (metaterminolization), and from these to common language (vocabularization), and in a contrary direction, from general language to the specialty languages (terminolization) (Barbosa, 1998), in search for the characterization of transposition processes, its semantic and pragmatic dimensions, no register, at last, the panchrony of the object. We can affirm, even if the panchrony of the object, clearly perceptible, has conducted, in our time, the approach panchrony.

In the previous item, we show a terminological field in statu nascendi. We will consider, here, as an example, a transpositio in prcesentia. We can verify the transposition of concept, conceptual semas, of terms in a full act of passage from one area to the other: a living example of instauration of an isoformism (the same projected form in different substances) between terminological fields of two very distinct areas - the biotechnology and business administration. We can observe the text:

\section{"THE TRANSGENIC ENTERPRISE"}

After decoding the human genetic code, there are people trying to understand the enterprise genome. His name is Laércio Cosentino, president of Microsiga, the largest Brazilian software company. Consentino is publishing a book, having as co-writers his 
colleagues Ernesto Haberkorn and Fernando Cícero da Silva, in which they explain how Microsiga, founded in 1983, got where it is nowadays. The secret: genes.

Human being has 32000 genes, and the plants, 25000. What about a company? According to Cosentino, a company has 20. They are listed in the next picture. "All of them are essential for an organization to be well succeeded in its actions", says Cosentino. "The enterprise genome can be used so a company, as long as it exists, try do differentiate from its competitors. "The rule could be to use a great number of genes, all the time. Our experience proved that using only a few of these genes isolated is not a guarantee of success", Cosentino affirms.

The Microsiga executives not only define and divulge the genes, but also keep in touch with their utilization - in other words they calculate what they call enterprise genome. It can be used in a specific way, for a specific project, or to measure a genetic influence of an entire corporation. That does not involve complicated calculations - the methodology, in reality, is very simple but the most difficult task id to obtain all the data to calculate it.

Imagine that you want to calculate the genetics of a determined project. The first step is to define which genes will be used. "It is clear that the ideal is to use the greater number of genes as possible", says Cosentino. "But not all of them will be always used". The global gene of thinking could be not necessary in the development of a local process, for example".

"DNA"

The enterprise genes, according to the executives of Microsiga. When combined they guarantee the success of an enterprise.
1. Perception and vision gene
11. Gene of versatility
2. Observation and analysis gene
12. Daring gene
3. Leadership gene
13. Focus gene
4. Gene of dynamism and execution
14. Ability gene
5. Gene of decision
15. Relationship gene
6. Opportunity gene
16. Team spirit gene
7. Pioneering gene
17. Gene of respect for life and community
8. Competitivity gene
18. Gene of knowledge dissemination
9. Global thinking gene
19. Gene of quality of life, products and services
10. Gene of regional thought
20. Gene of innovation

The second step is to calculate its real utilization - the genetic input of success. After the project has been concluded, we should verify which genes were really used and 
which ones were not used at all. Going back to the hypothetic example in the previous point: if 18 genes were used efficiently, the genetic input was $90 \%$ successful.

Based on an analysis such as this one, the company could put together and compare the results of various projects to obtain the average genetic input of a determined period. "Therefore it is possible" to evaluate the genetic profile of all the projects in a company says Cosentino. Monthly and annual comparisons could also be done with the objective of evaluating the success of using genes in a long term.

The same way biotechnology can alter the genetic material of a person, the enterprise genome can also be changed. "It is possible to include or exclude a determined gene or to induce mutations during its utilization", says Consetino. "These manipulations could permit to completely change the destiny of an enterprise". Does that really happen? That is a difficult answer. We cannot say that there is something obvious in Cosentino and his colleague's theory. Leadership, pioneering or focus, among other concepts, are fundamental for any kind of business - whether that are called genes, values, competitive differentials of any business. The question, in any organization, is to put things in practice. Cosentino affirms that, at least in Microsiga, this was the greatest contribution of the new genomic theory" (Herzog, 2001).

\section{Proposition of a methodological path for building a concept.}

Analyzing the contexts that sustain and manifest this complex formation - in this case, context that constitute the texts from specialists and of the media - from which conceptual traits are extracted, that form a concept, we can verify that some of these contexts privilege the stictu sensu concept, other the metaconcept and other the metametaconcept.

We propose, next, a model of conceptual-terminological form that allows the description and analysis of these three levels of construction of a concept: 


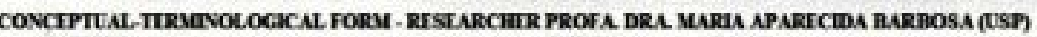

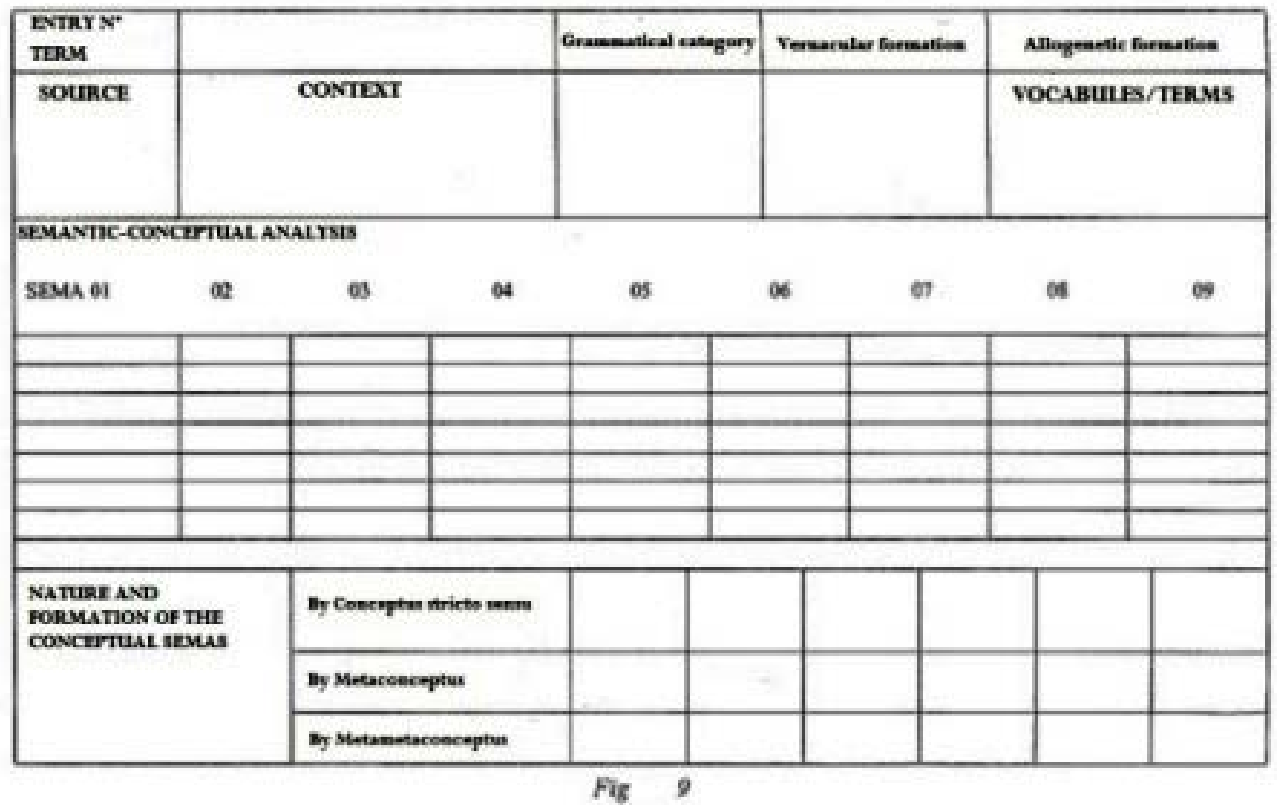

This conceptual terminological figure allows us, as we have said, the registration of the contexts in which the conceptual characterizers of a term present themselves. It also allows, identifying the group of semantic conceptual traits, distinguishing the ones that form the strictu sensu concept or of the metaconcept, or metametaconcept, relating one to the other, and at last, to the vocabules/terms that they manifest.

Therefore, for example, in the context of "The Government is rushing to clear out all the doubts that involve the genetic modified organisms... The Brazilian Government is convinced that should make clear, as soon as possible, all the points concerning genetically modified organisms in the country. That emphasizes the strictu sensu concept.

The concept, "Americans accept well the transgenics. A research done in October by GMA - Grocery Manufacturers of América, show that the Americans see biotechnology as a source of concern and that they did not change their food habits after the introduction of food that came from originally genetically modified plants in the market. Besides that, the research also shows us that the great majority of the Americans believe that biotechnology is a way of improving the agricultural practices and the quality of the food. It seems very clear however, that in many countries the increasing of the productivity will happen with the use of biotechnological resources, with genetic modification, highlighting the metaconcept.

As to the group of semantic-conceptual traits, they are the ones in Figure 7, presented before. 
It is important to observe that the configuration of the latu sensu concept is a process that precedes the definition process. It constitutes in its own form of content. In other words, the concept, the group of ordained conceptual traits, is within the definition, but they adequate to the syntactic-semantic structure, its form of contents and expression, required by this kind of paraphrased speech, in which the conceptual traits are organized In the form of a phrase, that is, manifested as metaterms. We could even highlight, that in a terminological dictionary, the two ideological sub-groups, the metaconcept and the metameta concept, should have explaining notes, a field that exists in the microstructure of the entries in a terminological dictionary.

\section{The formation of the concept in different nature speeches.}

As we have said in the previous item, examining the contexts that sustain and manifest the complex formation of the concept, in the case of the technological/scientific speech, the contexts that are constituted by the texts of specialists and of the media, from which conceptual traits are extracted, that produce this concept, or in the case of the literary speech, or, even in the case of different social non-literary speech, we can verify, that in some of these concepts strictu sensu concept is privileged, in other the metaconcept, and other the metametaconcept, always in a dialectic relation of presentification of the existing traits in the system and the incorporation of new traits that come from the specific circumstances of the enunciation and of the enunciation that is presented.

Therefore, in each universe of speech the process of engendrating of the concept has very specific aspects, that could require a detailed exam, since this process, among other marks, could characterize in a very important way the universe of the speech, while classes of speech or of manifested speech. In this way, the process of emphasizing, or the stritu sensu process, or metaconcept, or metametaconcept, as well as the process of creation of these conceptual sub-groups, these universes, along the way realized by the enunciator of the speech In question, in the phases of the enunciation - from cognition to semiosis - constitute relevant differentiators in each one of them. Only thee two aspects will be considered here, because the exhaustive examination of all the brands of the universes of speech could escape the limits of this article.

Before that, however, it seems necessary to one more time begin, at this moment, the conception of universe as formalized by PAIS:

Tomando-se a noção matemática de universo, como «conjunto de todas as partes», torna-se possível elaborar uma concepção muito útil, o metamodelo de universo de discurso. Assim, este pode ser definido como um conjunto não-finito ou que tende $\boldsymbol{a d}$ infinitum, de todos os discursos manifestados que apresentam determinadas características e constantes, assim como determinadas coerções, suscetíveis de configurar uma norma [...] A norma discursiva que lhe

Vol. 25 - Ano $44-n^{\circ} 2-2020$ 
corresponde, definida por tais características comuns e constantes, bem como por tais coerções, configura, portanto, um conjunto de critérios de equivalência, pelos quais é lícito reunir diferentes discursos manifestados, discursos-ocorrências, numa classe de equivalência discursiva, o universo de discurso considerado. Essa norma é dinâmica, seja porque se reformula continuamente, ao longo do eixo da História, seja porque sofre a interferência de normas de outros universos de discurso. O sujeito falante-ouvinte dela tem ou pode ter uma noção intuitiva, ao passo que, do ângulo científico, assume sempre um valor estatístico (constante em relação a variáveis) e nunca imperativo, já que um único e mesmo discurso manifestado poder pertencer, simultaneamente, a mais de um universo de discurso, como, por exemplo, o científico/pedagógico. Por outro lado, semelhante norma de universo de discurso compreende, na verdade, uma série de normas frásticas, lexicais, sintáticas, semântico-sintáticas e, por vezes, fonético-fonológicas, e outras tantas normas transfrásticas, narrativas e discursivas. Relativas à argumentação, à veridicção, à verossimilhança, ou à eficácia e às relações entre estas, às concernentes aos mecanismos de persuasão/ interpretação, de manipulação e contramanipulação, a formulações específicas das relações enunciado/enunciação, das relações intersubjetivas e espaçotemporais, como, ainda, as que dizem respeito às modalidades e às modalizações discursivas dominantes, ou às que estariam, em princípio, excluídas, e, enfim, aos processos de produção e sustentação de ideologia próprios aos diferentes universos de discurso. (PAIS, 1984: 44-45).

To these rules we think that it is necessary to add two processes listed above, that is, the rules they refer to, respectively, to then process of creation of the concept, conceptual modus operandi, the instance of the actualization of the speech, and to the process of selecting pregnancies, in the building of the latu sensu concept, that self-conclude, as a product, in the realized speech, not only in technical-scientific speeches, but also in the literary speeches in distinct social non-literary speeches.

We should remember the words of Greimas, concerning the organization of the figurative and non-figurative speeches:

"O rápido progresso de nossos conhecimentos sobre a organização dos discursos figurativos (folclore, mitologia, literatura) suscitou esperanças quanto à possibilidade de uma classificação e de uma regulamentação das formas narrativas que dessem lugar a uma gramática e a urna lógica narrativa [...] Reconheceu-se, em seguida, a impossibilidade de construir gramática discursiva que não desse conta, também, dos discursos não figurativos — ou que assim o parecem -, que são os discursos desenvolvidos no vasto domínio das "humanidades", que desconhecesse os discursos que desenvolvemos nós mesmos em ciências do homem" (Greimas, 1976: 3).

As to the process of construction of a concept, conceptual modus operandi, we could highlight, before everything else that this process can be vertical - from the fact to the cognitive level - or can be started in the syntagmatic relations of a manifested speech, in which the author will built, step by step, in his text, a concept. In the second process, the combination of occurrence-words, will slowly configurate the conceptual picture, 
that the author has a fact. From another angle, there is the path that takes the manifested discourse as a starting point, to arrive again at the conceptual level, which characterizes the enunciatary subject's interpretive making, or, in other words, a semasiological process, from sign to concept, done by who hears and who reads; we will qualify in this way, the lexicographic-terminographic path, as a process in which part of the manifestation of the lexemic level, with the selections, restrictions and semic combinatory in the speech, to achieve in a meta-speech equally configured as interpretative doing, articulate semas represented by lexematic metaterms, operation in which definition results.

Still under the perspective of the process, we should observe that the construction of the concept the fume semantical characteristics, sintatical, semiotical, and many pragmatic, if they occur in specialty language or in the literary speeches and or in other social non-literary speeches: the way of engendrating of a concept is, of course, based on the universe of speech.

We can highlight here, a very relevant difference: in the scientific speech, subject and anti-subject frequently correspond to the people involved; in the literary speech, subject and anti-subject are installed in the text by the author. In the scientific/technological speech, the engendration of a concept generally occurs in intertextual/interdiscursive relations among various researchers simultaneously to the formulation of the theory it contains; in the literary speech, a work can be self-sufficient, in the engendration of a concept, in a intertextuality intra and inter discursive. In the technical/scientific speech, theoretical and/or practical, as in the literary speech, the engendration of the concept is syntagmatic, narrative, transphrastic; in the terminological speech, it is mainly paradigmatic, as a process and final product, even if it results from extraction of contexts of transfrastic nature.

As to the enunciation, we need to consider the actancial action of the enunciating subject. In the technical/scientific speech, an individual and/or collective actor is converted, that sustains in a whole sense, the "vision of the world", the cultural highlights of the scientific community and of the area of specialty that is taking place; in the literary speech, we have as a rule, an enunciating subject that converts itself, in the discursive structures, in an actor (the author can, for example, or his pseudonym, or a delegated actor, etc.); in the journalistic speech and in the political speech, even if it is manifested as an actor, that leads to the actancial being of a collective enunciating subject, in a way that should represent aspirations, expectancy, demands of a political party, of a social class, of a professional group.

However, in the relations that are established between the concept, at the semantic/ cognitive level, the thematization and or the figurativization, in the semiotic level, as well as in the process of the enunciation reside, as to the process, the major differences among the universes of speech. In a general way a concept is: converted, in the gerative path of 
the enunciation, in themes, abstracts, and in figures that shape the body, the thickness of the idea, highlighting its effects in the sense of veridiction, or similarity, understood as a theme the semiotization of the concept, by thematization, the construction process of abstract ideas, and by figuratization, the process of embodying of these ideas. From them results the thematic and figurative isotopies, as processes of semic redundancy. In these conditions, a philosophical speech, for example, tends to be more abstract, with a greater incidence of thematic isotopies; a literary text tends to be more figurative, with great abundancy of figurative isotopies, even if these distinctions will ever be excludent. In other words, distinct pictures are made, taking as a starting point latu sensu concepts, mental models. In the political, journalistical, publicity speech, the re-elaboration of a concept, in the semantic/cognitive level, results from a team work, in a way they search to capture and/ or rebuilt the collective imaginary of the society or of a social segment. The enunciating subject of the political speech, for example, generally does not speak in his own name but in the name of the directives of his party and of the interests that this party tries to defend. In this way, the process of cognition, of continuous rebuilding of the knowledge about the world takes specific characteristics, once it is intimately related to the process of "world formulation", the construction of a "vision of the world" of this group, in this way, for example, of the semiotically world built by the political groups that defend the interests of the great rural proprietors.

In this same way, we can distinguish the engendration of the fear concept, when treated in a scientific speech as the one in medical clinic, or when it is processed in a tragedy, in theater.

Therefore we can also take as starting point, in the conceptualization, the concepts of love, death, happiness/unhappiness, possible/impossible and conduct them to converge in theme, in the semiotic level, trying to reach "impossible love". From this angle, it is legitimate to relate Romeo and Juliet and Black Orpheus. However they clearly differentiate, as related to figurativization, specialization, timing, in the discursive structures. This permits us to propose the following scheme:
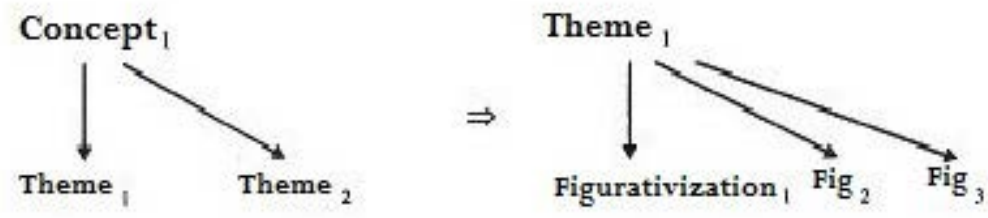

Fig. 10 - The concept and its semiotization 
This means that in the path that goes from conceptualization to semiotization, there was a selection of semantic-conceptual traits and the corresponding extract from the preexisting cultural extract, linked to the constant and coercions characteristics in the universe of speech. In other terms, the pregnancies are redirected.

This dominance of certain elements of the concept above other, constitute a "choice" of the enunciating subject in the process of enunciation. One of the aspects that characterizes the specificity of the cognition, in different universes of speech, are the distinct pregnancies of a same fact: each universe of speech, learns and elaborates again certain semantic/ conceptual traits, leaving other traits in latency. Consequently, the concept will be themed and figured, in the semiotic level, according to the pregnancies of the enunciating subject.

As to the conceptual subgroups that emphasizes the different speeches, process (B), we can say that the technical/scientific speech, tends to privilege the strictu sensu concept - subgroup of the traits that serve the conceptualization of natural semiotics - and, yet, in the speeches that circulate in the scientific international community, the archiconceptus, multilingual and multicultural. The literary speech tends to emphasize the metaconceptus - a sub-group of semantic conceptual cultural traits, producing simultaneously, a change in the cultural arena, that comes from a particular reconstruction of the world built semiotically. The political speech and the journalistic speech, for example, tend to highlight the metametaconceptus, sub-group of modeling, manipulators traits, trying to reach a discursive efficiency. In scheme we have:

\begin{tabular}{|c|c|c|}
\hline $\begin{array}{l}\text { Universe } \\
\text { of speech }\end{array}$ & $\begin{array}{l}\text { Modus operandi } \\
\text { conceptual }\end{array}$ & $\begin{array}{l}\text { Tendency to dominance } \\
\text { of conceptual subsets }\end{array}$ \\
\hline $\begin{array}{l}\text { Terminological } \\
\text { speech }\end{array}$ & $\begin{array}{l}\text { eminently } \\
\text { paradigmatic }\end{array}$ & $\begin{array}{l}\text { conceptus stricto sensu } \\
\text { arquiconceptus }\end{array}$ \\
\hline $\begin{array}{l}\text { Technical- } \\
\text { scientific } \\
\text { discourse }\end{array}$ & $\begin{array}{l}\text { paradigmatic- } \\
\text { syntagmatic }\end{array}$ & $\begin{array}{l}\text { conceptus stricto sensu } \\
\text { arquiconceptus }\end{array}$ \\
\hline $\begin{array}{l}\text { Literary } \\
\text { discourse }\end{array}$ & $\begin{array}{l}\text { eminently } \\
\text { syntagmatic }\end{array}$ & metaconceptus \\
\hline $\begin{array}{l}\text { Other non-literary } \\
\text { social discourses }\end{array}$ & $\begin{array}{l}\text { eminently } \\
\text { syntagmatic }\end{array}$ & metametaconceptus \\
\hline
\end{tabular}

\section{Semiotization and Context of the Concept.}

The fourth moment of the gerative path of the eniciation of encoding is the leximization, that corresponds to the conversion of the concept in size-signus, semiotic function and/or metasemiotics functions, that is, the passage from the cognitive level to 
the semiotic level, the configuration of the concept in signification, precedes its update in a concretely realized speech.

We should make at this point some observations. In the process of conversion from the latu sensu concept into lexical unit, the three sub-groups of the first - archiconceptus, metaconceptus, metametaconceptus - transformed into linguistic semas, will constitute the semema of this lexical unit, and that, at a system level, is characterized as polysemic and, many times, polysemic, that is, the sobressema, not only because it contains the semantic traits of the three sub-groups already mentioned, but also because it contains, eventually, semantic traits of other latu sensu concepts. That is, for example the lexical unit piece considered in a system level.

On the other hand, a concept can be represented, in this instance of semiotization, by one or various lexical units, respectively, unitary or multiple lexical fields, in a same text or in distinct texts.

From another angle, a lexical unit can integrate various lexical fields, in a system level and of speech, due to the parts that it sustains and of the network of relations that are stablished among equal concepts, in the different universes of speech. Therefore, for example, freedom belongs to a semantic field in the political speech, in the expression freedom, equity, fraternity and belongs to the publicity speech in the expression "you have more freedom using a credit card x ...”. In the first case, the concept of ideal of democracy and the Rule of Law, in the second case, to the concept of financial power.

We observe, yet, that these processes are done with any kind of lexical units simple, composed, complex, textual - that in this level of system, integrates the competence instance that precedes and authorizes it being updated in a manifested speech.

In the process of contextualization, we have an epissemema (simultaneously, with the reduction of the semas end sobressememas, that is, the selection determined by a situation of speech and of enunciation, and the adding of semas to the context, in the syntagmatic combinatory), from which it results the semiosis. In this level, the lexical units of the manifested speech that represents the same latu sensu concept may occour as a semiotic function, or as metassemiotic latu sensu.

It is fundamental not to mix them, but distinguish them, very clearly, in one side, the relations that are stablished between the subgroups of semantic/conceptual traits of the latu sensu concept, that are in the same semantic/cognitive level, inter and intra-conceptual relations, and, on the other side, the relations of significance, that are stablished, therefore, in the semiotic level, between denotation (size-sign, ERC), connotation (metaphor, metonymy (ERC)RC) and clearly able to build the metassemiotic, ER(ERC)). 
We believe it is not too much, repeating that the sign-occurrence may update one or another subgroup, or even three subgroups of the latu senu concept, without being in a connotative or metassemiotic function, as referring to the relation of the signs that were used, as basis. In this case, the relation that is established is between sign-sign, and semiotics-semiotic function.

That is, for example, science and competence have a signification, as vocabules, in common language, are terms in epistemology and metaterms in the semiotic octagons elaborated by PAIS (1993:617).

\section{Conclusion}

We proved the organizational diversity of the concept, with its successive groups of characterizing traits - from biological to ideological - as well as the existence of the neutralization process, also in the conceptual level, that results in the archiconcept. We were able to build models that permited the description of the unitary and multiple conceptual fields, of its respective archiconcepts and metaconcepts, in a perspective mono and plural language. We also were able to propose a methodology of engendrating concepts in the terminological domains. The model was applied to the analysis of the formation of concept that corresponds to the term transgenic, showing very satisfactory results. We not only showed the conceptual configuration, more and more clear and precise, of transgenic, as well as its respective terminological field, in status nascendi. We also showed, in a panchronic approach, the transposition of concept/term, in the area of biotechnology to the area of enterprise administration, trying to highlight the multifunctional nature of concepts, conceptual fields, lexical fields, terminological fields.

We also observe, relevant aspects concerning the conceptual modus operandi and the direction of pregnancies, as possible characters, among other, of specialty languages, literary speech and social non-literary speech.

\section{Bibliographical references}

BARBOSA, Maria Aparecida. Terminologização, vocabularização, cientificidade, banalização: relações. Acta Semiotica et Lingvistica. São Paulo, V.7, p.25-44, $1998^{\mathrm{a}}$

Paradigmas de criatividade léxica. Homage à Simone Saillard. Testures. Cahiers du CEMIA. Lyon, Département de Langues Romanes de 1'Université Lumière Lyon 2, p.385-405, 1998 b.

Campo conceptual e campo lexical dos termos globalização e mundializaçao: relações. Revista brasileira de linguística. São Paulo, v. 10 P 29-52, 1999. 
Estruturas etipologiadoscamposconceptuais, campos semânticose campos lexicais. Acta Semiotica et Lingvistica. São Paulo, v. 8, p. 95-120, 2000.

BÉJOINT, Henri., THOIRON, Phillippe ed al. Notion d" "archiconcept" et dé- nontination. Meta. Journal des Traducteurs. Montréal, P'resses de l’Université de Montréal, p. 512$523,1996$.

CABRÉ, Maria Teresa. La terminología. Teoría, metodología, aplicaciones. Barcelona: Editorial Antartida/Empuries, 1993.

GREIMAS, Algirdas Julien. Semiótica do discurso científico. Da modalidade. Tradução de Cidmar Teodoro Pais. São Paulo: DIFEL-SBPL 1976.

HARRIS, J.P. O que você deve saber sobre os transgênicos. Seleções. Rio, The Reader's Diget, p. 101-105, outubro de 2000.

HERZOG, Ana Luiza. A empresa Transgênica. Projeto Genoma Corporativo. Revista Exame. São Paulo: Ed. Abril, p. 125 e 126, 16 de maio de 2001.

HJELMSLEV, Louis. Prolegômenos a uma teoria da linguagem. São Paulo. Perspectiva, 1975. PAIS, Cidmar Teodoro. Aspectos de uma tipologia dos universos de discurso. Revista brasileira de linguística. São Paulo, v. 7, p. 43-65, 1984.

Conditions semântico-syntaxiques et sémiotiques de la productivité systématique, lexicale et discursive. These de Doctorat d'Etat és-Let- tres et Sciences Humaines. Paris/ Lille: Uníversité de Paris-IV, ANRT, 1993.

Conceptualisation, dénomination, désignation, référence: reflexions à propos de l'érionciation et du savoir sur le monde. Homage à Simone Snillard Textures. Cahiers du C.E.M.IA. Lyon, Université Lumiére Lyon 2, p. 271-311, 1998.

Semântica cognitiva, noêmica, semântica lexical e semiótica das culturas. SILVA, Dinorá Fraga da. e VIEIRA, Renata. (Orgs) - Ciências cognitivas em semiótica e comunicação. SãoLeopoldo: Ed.Unisinos, p. 13-50, 1999.

PEREIRA, P.eALISKI, A. Campanha para promover os transgênicos. In Gazeta Mercantil. São Paulo, pág. A-12, 04/09/2000.

POTTIER, Bernard. Théorie et analyse en linguistique. 2 éd. Paris: Hachette. 1991. Sémantique générale. Paris: P.U.F., 1992.

RASTIER, François. Sémantique et recherches cognitives. Paris: PUF, 1991.

Para uma poética generalizada. Tradução de C. T. Pais. Acta Semiotica et Lingvistica. São Paulo, v.8, p. 445-470, 2000. 
EDITORIAL.Americanos aceitambemostransgenicos. CorreiodoEstado,Campo Grande: $6-\mathrm{A} ; 25 / 10 / 2000$.

EDITORIAL. Recomendações sobre os transgênicos. Informativo do Instituto de Estados Avançados da Universidade de São Paulo. São Paulo, ano XII, p. 1, outubro/novembro 2000. 